\title{
Christology and Christianity: The theological power of the threefold office in Lord's Day 12
}

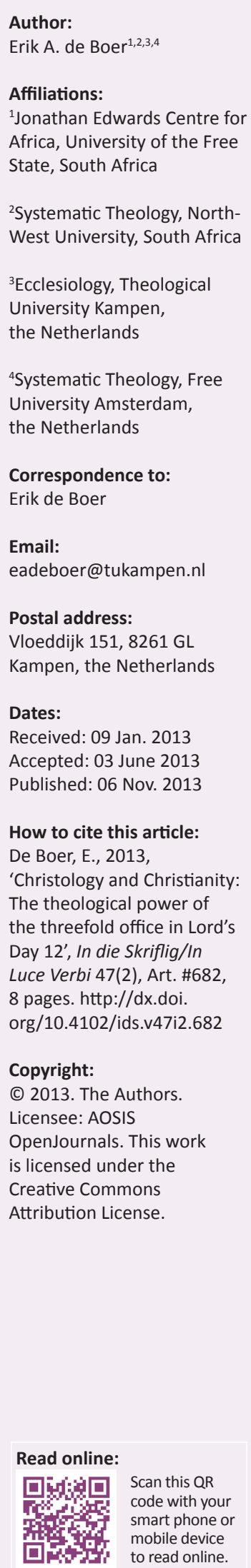

The concept of the threefold office of Jesus was developed in the explanation of the name Christ. The three distinct offices of king, priest and prophet in Israel are thought to be united in the one Messiah. Since the unity of all three offices in one person is not found in so many words in one specific text from the Bible, it is regarded as a theological concept. As such it was developed for the first time in the Heidelberg Catechism (HC). This article traces the development of the exposition of the Apostles' Creed in earlier Lutheran and reformed catechisms. Special attention is devoted to the one by Johannes Brenz, which was used in the Palatinate before 1563. The main source of the new Catechism of Heidelberg is the Catechismus minor by Zacharias Ursinus, who himself may have been influenced by Martin Bucer and John Calvin and their respective Catechisms. A special feature of the $\mathrm{HC}$ is question and answer (Q/A) 32, devoted to a parallel exposition of the name Christian. Caspar Olevianus' work Vester Grund (A Firm Foundation) is read as a contemporary commentary on the exposition of the Creed. The catechetical power of the concept of Christ's threefold office is finally demonstrated in its use in systematic theologies as by Gerrit Immink and Michael Welker, especially in their Christologies.

Christologie en die Christelike geloof: Die teologiese krag van die drievoudige amp in Kategismussondag 12. Die konsep van die drievoudige amp van Jesus is ontwikkel in die verklaring van die naam Christus. Die drie onderskeie ampte in Israel, dié van koning, priester en profeet, word gesien as verenig in die Messias. Aangesien die vereniging van al drie ampte in een persoon nie soseer in een spesifieke Bybelteks gevind word nie, word dit as 'n teologiese konsep beskou. Dit is sodanig vir die eerste keer in die Heidelbergse Kategismus (HK) ontwikkel. Hierdie artikel ondersoek die ontwikkeling van die uiteensetting van die Apostoliese Geloofsbelydenis in die konteks van vroeëre Lutherse en gereformeerde kategismusse. Daar word veral na Johannes Brenz se Kategismus, wat voor 1563 in die Pfalz gebruik is, gekyk. Die vernaamste bron van die Heidelberger is die sogenaamde Catechismus minor van Zacharias Ursinus, wat weer deur Martin Bucer en Johannes Calvyn en hul onderskeie Kategismus beïnvloed is. 'n Uitstaande kenmerk van die Heidelbergse Kategismus is vraag en antwoord (V/A) 32, wat aan 'n parallelle uiteensetting van die naam Christen gewy is. Dit kan aan die hand van die Engelse vertaling van Caspar Olevianus se werk, A Firm Foundation, verduidelik word. Die kategetiese krag van die konsep van Christus se drievoudige amp word gedemonstreer in die gebruik daarvan in sistematiese teologieë, soos Gerrit Immink en Michael Welker se Christologieë.

\section{Eusebius on the 'Christian' Church}

In the early 4th century, Eusebius of Caesarea (1973) wrote in the introduction to his Historia ecclesiastica that the truly anointed One (Christos):

... the divine and heavenly Word is the only high priest of the world, the only king of all creation, and of the prophets the only arch prophet given by the Father. (Hist. eccl. 1.3.8)

Eusebius is the first Christian author who explained the name Christ in a threefold repetition of 'he is the only one' (monon) and with reference to three Old Testament offices. According to him, the name Christ was revealed to Moses and later prophets, and pictured in the symbol of anointing. This way, high priests, kings and prophets 'were decorated with the name "Christos"'. Having attributed the three offices to Jesus Christ, Eusebius (1973) underlined this as follows:

Proof of this is that no one of the men of old, anointed with the symbol, neither priests nor kings nor prophets, obtained such power of divine virtue as our Saviour and Lord, Jesus, the only and true Christ. (Hist. eccl. 1.3.9)

The author (Eusebius 1973) of the first history of the church brings this application home by stating that also not one of the anointed men of old ever gave the name Christianos to their subjects. Jesus, however, 'being himself the one and true Christ of God, he has filled the whole world with Christians' (Hist. eccl. 1.3.12). Both this explanation of the name Christ and the application to the Christian name was styled and incorporated into the $\mathrm{HC}$ in a unique and influential way. 
At the end of the 4th century, the Greek father John Chrysostom (1862), commented on 2 Corinthians 1:21:

What does it mean: 'Anointed and sealed'? It is the Spirit, by whom he brings about both, making at the same time prophets, priests, and kings. For of old these classes of people were anointed. But now we have not received (only) one of these dignities, but all three preeminently. For we will be enjoy the kingship and become priests, offering our bodies instead of sacrifices, for it is said: Present you bodies as a living sacrifice, acceptable to God ( $\operatorname{Rm} 12: 1)$. Moreover, we have been appointed as prophets, for what no eyes have seen, nor ears have heard, these things have been prepared for us (1 Cor 2:9). And in another way we have also become kings, if we have been willing to rule over foolish thoughts. (p. 411)

Fastidius, a Latin bishop working in Brittany around 430 and with affinity to Pelagius, began his work On the Christian life (De vita Christiana) with a chapter on 'the name and dignity of the Christian'. He pointed to Christ's name and the meaning of unction. No other men have been anointed except the holy and worthy, and no others than prophets, priests and kings. To answer for the discrepancy between 'the holy and worthy' and the bearers of the three offices, Fastidius (1865) proceeded:

And so great was the mystery of this anointing that not all in the Jewish people proved worthy to receive it that rather few of the many. And so it has been until the coming of our Lord Jesus Christ, whom God has anointed with the oil of gladness [that is, with the Spirit] before your companions (Ps 45:7). But from that time those who have faith and are purified by the sanctification that baptism, not some, such as it had been earlier under the Law, but all have been anointed prophets, priests, and kings. (pp. 383-384)

The holiness of the sacrament points to a holy life. This is what the name Christian, for those who believe in Christ, entails (Fastidius 1865:385).

\section{Revisiting Heidelberg Catechism Lord's Day 12}

The basic structure of most catechisms is the exposition of the Apostles' Creed, the Decalogue, and the Lord's Prayer. In the course of the discussion of the first ecumenical Creed, teacher and pupil arrive at the names of our Lord, Jesus Christ. One section in the HC, comprising of two questions and answers, is dedicated to the name Jesus (Lord's Day 11), another to his office as Christ, the anointed One (Lord's Day 12). This article is dedicated to this basic meaning of the original Greek word Christos, a rendering of the Hebrew Masshiach, with its roots in Old Testament history and its application in catechetical instruction in the 16th century.

The following questions will be addressed:

- What are the theological sources of this exposition of Jesus' threefold office?

- What is the catechetical bearing of this concentrated discussion of the official name Christ and the application to the appropriation of the name Christian ${ }^{1}$

- What was the theological influence of the concept of the triple office since HC?

1.For the state of scholarship see the chapter on Christology in Handboek Heidelbergse Catechismus (Huijgens, Fesko \& Siller 2013:232ff.).
The focus on one specific section of the HC is presented as an example of a more general approach to the sources. To show how these texts can be studied, even without access to printed editions or knowledge of German or Latin, we will point to digitally accessible sources and translations.

We will compare the same topic in a variety of contemporary catechisms and show the way to these 16th century sources. Our starting point is M.A. Gooszen's collection (1890) of texts in De Heidelbergsche Catechismus of 1890, which is digitally accessible. On Lord's Day 12 he provides the parallel text of Zacharias Ursinus' Catechismus Minor (1562b) and Maior from Heidelberg (1562a), from Zurich two catechisms by Leo Jud (in 1534 and 1535) and one by Heinrich Bullinger (in 1559), the Genevan Catechism of 1545, and the London Catechism by Marten Micron (in 1552; cf. Lang 1907). The works of Zacharias Ursinus and Caspar Olevianus are now accessible on the website of the Post-Reformation digital library. The bibliography also supplies information on more recent editions of these sources. This article is the author's continuation of a study of the marks of the Christian in the Belgic Confession's article 29 (De Boer 2009).

\section{God's threefold rule of Israel}

Question 31 provides the information that the name Christ means 'the anointed one'. There are some implications in Q/A 31 that are not clarified in the text, but await explanation by the catechist. On this hidden agenda is, for example, the Bible story of Israel's kings, of the priests serving in tabernacle and temple, and of the Old Testament prophets. The succession of kings from the house of David, the generations of priests and Levites, and the wide variety of prophets throughout the realm and the times, offer a range of personalities that illustrate their specific office. These three offices tell the styled story of God's rule over Israel in Old Testament times. Even the ages following the Babylonian captivity show how God's people fared when the functioning offices were taken from them. The wrath of the Lord has come upon his people when the throne of David is empty, the temple is destroyed and prophets are few and far between.

The structure of the threefold office in Israel also serves as the matrix for teaching the story of the New Testament. Jesus Christ is revealed when an Edomite king sits on the throne of David, when the high priest is not anointed by his father, but appointed by the Romans, and when the Lord's prophet - comparable to Elijah - is decapitated.

Also implied in Q/A 31 is the fact that Jesus was never anointed according to the rites of Old Testament law, that is, with the sacred oil of Exodus 30:22-33. His public calling is not called chrisma in the Gospels, but baptism. Not the sacrament of unction, but the reality of the Holy Spirit's descend is visualised. It is especially Psalm 2, quoted in the New Testament, which helps to bring out the implied meaning. The letter to the Hebrews is used to interpret the connection between the Aaronic priests and Jesus. 
Thus, the name Christ is taken as a powerful catechetical tool, serving to imprint the structure of God's threefold rule of Israel as a reading device for the Old and New Testament history and to follow these lines to discover the unique character of Jesus Christ (Mühling, A. \& Opitz 2009 [RB 2/2]):

Question 31: Why is he called 'Christ', that is, anointed?

Answer: Because he is ordained by God the Father, and anointed with the Holy Ghost, to be our chief Prophet and Teacher, who fully reveals to us the secret counsel and will of God concerning our redemption; and to be our only High Priest, who by the one sacrifice of his body, has redeemed us, and makes continual intercession with the Father for us; and also to be our eternal King, who governs us by his word and Spirit, and who defends and preserves us in that salvation, he has purchased for us. (p. 183)

The Old Testament ritual of anointing remains a powerful visualisation of the inner workings and abundance of the Holy Spirit.

\section{Johannes Brenz: The predecessor}

With the publication of this new catechism, the Lutheran catechism by Johannes Brenz from the year 1553, was replaced. His Pious Catechism, Enriched by Useful Explanation also followed the Apostles' Creed, but lacked the structure of questions and answers. The name Christus is used as a cognomen for Jesus and is explained from the Greek and rendered in Latin and German. The first Old Testament reference is to Mosaic law on the unction of priests (Ex 29) and kings. Thus, kings were called messiahs (Messiae), as Saul and David were, and even patriarchs (see Ps 105:15) or Cyrus (Is 45:1). But most fitting is this name for Jesus, our Saviour. $\mathrm{He}$ 'has been anointed with spiritual oil unto a heavenly and eternal reign' (Is 61:1).

After the full-length quotation of the Gospel on Jesus' baptism, this Catechism states (Brenz 1553):

This is the anointing of Jesus by which he - as the byname of Christ, that of King, states - is both dedicated to and invested with the possession and execution of his eternal reign. (p. 119)

It is clear that Brenz's Catechism relates the name Christ solely to his office as King. This office is then explained in a threefold sense: firstly to punish sin, then to be a just judge, and thirdly to expel the enemy so that the people can lead a peaceful life. The explanation is concluded as follows (Brenz 1553):

Of these important matters Jesus' name, which is 'Christ' has to remind us, so that we may reap real benefit from the recitation of the Apostles' Creed and otherwise from the occurrence of this word 'Anointed'. (p. 119-122)

Lacking a clear structure, Brenz's catechism was less useful for the children. Moreover, the Lutheran drift of its teaching on the sacraments was rejected by Frederik III of the Palatinate, who instructed a team of theologians in Heidelberg to draft a new form of teaching.

\section{Preparations by Zacharias Ursinus}

In 1562, Zacharias Ursinus composed a succinct Catechismus Minor (1562b) for children and an expanded Catechismus
Maior (Ursinus 1562a) for adults. The Minor has the following text as Q/A 20 (Latin text in Gooszen 1890):

Why do you say 'Christ', that is, 'the anointed'? ${ }^{2}$

That is because he has been appointed by his eternal Father and anointed with the Holy Spirit to be for me and for all faithful the highest Prophet, who reveals God's will to us; and to be our only High Priest, who reconciles us with God by his intercession and the unique offering of his body on the cross; and to be our King, who governs us through his Word and Spirit, guards the salvation won for us, and hands it over to us after this life as our perfect and eternal possession. (p. 52)

It is not hard to see the parallel with Q/A 31 of the Heidelberg Catechism: the threefold office of Christ and the order of prophecy, priesthood and kingship (different from Eusebius). This basic text is developed into five questions and answers in Ursinus' Catechismus Maior (1562a). Question 58 reads: 'What does the name 'Christ' means?', with the answer being: 'That he has been anointed by the Father as Prophet, Priest, and King'. Question 59 then specifies: 'By what kind of anointing has he been anointed?', with the Answer being: 'By the fullness of all gifts of the Holy Spirit'.

The reality of Christ's baptism by the Spirit is expressed and the content of the anointing in the gifts (dona) of the Spirit is made explicit. Then the three offices (note that the term munus or officium is not used) are treated as follows:

Question 60: Why do you call him prophet?

Answer: Because he has revealed to us through the ministry and the Holy Spirit in our hearts the Father's will for us. And he fulfils the prophecies and types which in the Old Testament pointed to him.

'The ministry' is, as will become clear in answer 62, the ministry of the Word as carried out by the servants of Christ. The priesthood, however, is operated only by Christ himself:

Question 61: What is his priesthood?

Answer: To gain grace from the Father by the intercession and offering both of his obedience and death.

Question 62: What is his kingship?

Answer: That is that the Son of God from the very beginning instituted and maintained the ministry of the Gospel, through which he converts and vivifies the elect, sanctifies them by the Holy Spirit, defends them against the devils, revives them to eternal life and ushers them into the very presence of the Father, so that the divinity might reign in them openly rather than through the ministry.

It is interesting that the ministry (ministerium, i.e. of the Word) is mentioned as the means by which Christ fulfils his prophetical office today. This element is thus implied in the present tense of answer 31 ('who fully reveals to us ...'). This ministry is the present means of Christ's rule as king and will be superseded when the faithful enter the kingdom of the Father.

Ursinus' Catechismus Maior, also written in preparation of the later task of working on the Heidelberg Catechism, can be read as the long version of what in condensed form became 2.For a translation, also see http://links.christreformed.org/doctrinevision/ursinus project.pdf (viewed 01 December 2012). 
Q/A 31. ${ }^{3}$ The gifts of the Spirit in Christ and his present rule by the ministry of the Word are points of doctrine that are in the background of Q/A 31. The element of the types from the Old Testament, also found in Brenz's Catechism, is less recognisable in, though not alien to, the Heidelberg Catechism.

\section{Bucer and Calvin}

Prior to Ursinus, the threefold office of Christ was taught by Martin Bucer and John Calvin. In his Enarratio in evangelion Iohannis Bucer provided linguistic and textual information on the meaning, use and prophecy of the Hebrew verbal form Messhiah in John 1:41. He summarises (Bucer 1528):

In those days kings, priests, and, prophets were anointed and thus inaugurated in their office. Yet Christ is the king of kings, the highest priest, and the head of the prophets, who does not rule by the external means of power, nor sacrifices stupid beast, nor teaches and chastises only by means of his voice, but he rules the minds, the willing ones, unto salvation forever. (p. 100)

Bucer, keeping the sequence that we encountered in Eusebius, referred to Psalm 45 and Isaiah 61 as prophecies of the Messiah. ${ }^{4}$ Having applied these to Jesus, he concludes (Bucer 1528):

Since therefore it was to this splendid realization that Jesus was destined by that divine anointing of the Holy Spirit, by right he had to be anointed for all God's children and by it be inaugurated in his reign, priesthood, and prophetical task (munus). And for this reason he is rightly called the Anointed, without any qualification, by antonomasia; it has the same bearing as if he would be called King. (p. 100) ${ }^{5}$

This emphasis on Jesus' kingship is found in Bucer's Catechism of 1534. 'What does the name "Christ" mean? The anointed one (Der gesalbet), which also means king, because in God's people they anointed the kings' (Bucer 1987:59). The following editions have even more pointedly stated: 'What does Christ mean? God's anointed king, who reigns God's children unto eternal life' (Bucer 1987:181, 234).

It is John Calvin who introduced the threefold office of Christ in catechetical teaching. His first Catechism of 1538, lacking the structure of questions and answers, already taught that Christ was anointed as king 'to cast down all might in heaven and on earth, so that in him we may become kings, having power over the devil, sin, death, and hell' (Calvin [1538] 2002:46-47). Secondly, Christ (Calvin ibid):

... was installed as priest to appease and reconcile us with the Father by his sacrifice, so that we may become priests, bringing to God prayers, thanksgiving, ourselves and all our things, having him as our intercessor and mediator. (p. 48-49)

3.See Zacharias Ursinus' five questions: 'Quid nomen Christi significat?', 'Quo unctionis genere unctus est?', 'Quare Prophetam dicis?', 'Quid eius Sacerdotium?', 'Quid est eius regnum?' in Catechesis, summa theologiae (Ursinus 1612a:15), unfolded in Explicationes Catecheseos Palatinae, sive corpus Theologiae (Ursinus 1612b:141-144).

4.The same sequence is still found in Marten Micron's De Kleijne Catechismus oft Kinderleere of 1552: 'Waerom is hy Christus, dat is Gesalfde gheheeten? Omdat Kinderleere of hy een eenich, eeuwich, ende opperste Koninck, Priester ende Leeraer zijnder Ghemeynden is: door wiens ordinancien, offerhande, ende leeringe alleene, sy gheregeert, ghereynicht ende geleert moet wesen, nae het getuygen der ganscher

5.Cf. Calvin's line 'Proinde merito Christi epitheton, per Antonomasian, salvatori nostro defertur' in Institutio (1539:125). See also d'Assonville (2013).
The office of prophet and its application to us, however, is missing. The same can be said of Leo Jud's Catechisms (Gooszen 1890:53-54).

It is remarkable that Calvin (1539) introduced in his Institutes a discussion of the meaning of the title Christus and presented the following order of those who were anointed: prophet, priest and king (Calvin 2008):

For it is suitable that a prophet, who has to be messenger of God among the people, was endowed by singular graces of the Holy Spirit; the same applies to the priest, who is called angel of the living God (Ml 2:7); finally the kings, who represent God's image on earth. (p. 609)

However, this order seems still rather random, because in the Latin edition the order varies: prophet, king and then priest (as in Bullinger's Catechismus plenior of 1559; see Gooszen 1890:54-55). This variation remains until the 1559 edition of the Institutes (Calvin 1559 Inst. II.15).

\section{Catechism of Geneva}

Calvin's clearest contribution to catechetical teaching on the office of Christ is found in the Catechism of Geneva of 1545. Answer 34 on the meaning of the name Christ says: 'By this title his office (officium) is even better expressed. For this means that he is anointed by the Father as king, priest and prophet' (French: Faulenbach, H. \& Busch 2006:295 [RB 1/2]; Latin: Barth \& Niesel 1970:79 [OS II]; Afrikaans: Calvyn 1542:10). The following question seeks to clarify how anointing is connected to the three offices and to Christ in Scripture. Being asked what kind of oil was used on Christ (question 36), the child is supposed to answer: 'Not with visible oil, as the kings, priests, and prophets of old, but with the gifts of the Spirit, who is the truth of the external anointing [which was used in times gone by]' (answer 36). Then follow three questions and answers on Christ's (spiritual) kingdom, his (personal) priesthood and being (God's) prophet. Calvin keeps the order found in Eusebius and Bucer. Thus, six questions and answers in Lord's Day 5 of the Genevan Catechism explain the title Christ.

Calvin developed this catechetical material even further by adding another six questions and answers in Lord's Day 6. These apply to the unction of Christ and his exercising of the threefold office to the children in church. For Christ has received all these gifts to let us participate in them (see Jn 1:16). Question 42 ('To what end does his kingdom serve?') is answered as follows:

That is being liberated in our consciences by him and filled by his spiritual riches to life just and holy, we also have the power to overcome the devil, sin, our flesh and the world, who are enemies of our souls. (A 42)

The material of 1538 is also developed in the question on the meaning of Christ's being priest (Q/A 43). According to Hebrews, we also have access to God (Heb 7-10) and also bring sacrifices (Heb 13). 'This way we are participants in his priesthood' (compagnons de sa Prestrise) (RB 1/2 2006:297). Finally, explaining the bearing of Christ's prophetic office, 
Calvin states that our Lord Jesus is Master and Teacher of his own, introducing us into the true knowledge of his Father and making us 'private students of God' (escoliers domestiques, Q/A 44). Most teachers in those days, including Calvin, had students who lodged in their home. These boys had more private access to their master than the others. Calvin does not call Christians 'prophets', but is mindful of teaching the catechism to schoolboys and girls. This step is taken, however, by the men who wrote the Heidelberg Catechism.

Lord's Days 5 and 6 of the Genevan Catechism are concluded with a long question of the pastor. That rhetorical question is (Q 45):

All that you have said then comes to this, that the name of Christ comprehends three offices which the Father hath bestowed on the Son, that he may transfuse the virtue and fruit of them into his people?

The child is of course to answer 'It is so' (A 45).

\section{The name of a Christian}

Even more remarkable than Christ's threefold office in this catechism is its application to the Christian. Eusebius pointed to the name 'Christians' to underline the unique character of Jesus as the 'Christos'. Calvin's first Catechism already had the application of Christ's kingship and priesthood to us. The address in the question in the Heidelberg Catechism makes this application even more personal.

Question 32: But why art thou called a Christian?

Answer: Because I am a member of Christ by faith, and thus am partaker of his anointing; that so I may confess his name, and present myself a living sacrifice of thankfulness to him; and also that with a free and good conscience I may fight against sin and Satan in this life and afterwards I reign with him eternally, over all creatures.

Faith in Christ, and not baptism (as Lutherans would have said), ${ }^{6}$ is taken as a parallel to anointing (see the example of Kaspar Huberinus' Der klainer Katechismus in Verboom 1996:117; 2008:228). No second blessing with the Spirit is known, but the Christian is blessed with spiritual gifts through Christ.

This second part of Lord's Day 12 has no parallel in Ursinus' Catechismus Minor (1562b). The Maior, however, reads as the final question and answer in this section:

Question 64: What then does it mean to believe in Jesus Christ?

Answer: It means that we have this comfort that by him as our king we are enriched and ruled by the Holy Spirit and protected from all dangers; by him as our high priest we are reconciled and led to the Father so that we can ask and expect all good things from him; and by him as the true prophet we are illumined with the knowledge of the Father; consequently with him we become kings, who eternally reign with him over all creatures; priests, who already now offer ourselves and all that is ours as thank offerings to God; and prophets, who truly know and glorify God. (1562a)

6.This fact immediately evoked the critique from Lutheran rulers, who wrote to Frederich III: 'dieweil aber dar thit mit name from disem Censori ein grosse sind [ disem Censon ein grosse sind (sunde, vergessenheit und unbescheidenheit sein (Gooszen 1893.129). Earlier in their critical response to the Heidelberg Catechism, they had already noted that faith should be central in any answer to the question 'Warumb bistu ein Christ?' (Gooszen ibid:89ff.).
In the process of the composition of the Heidelberg Catechism, this material was noted and brought in line with Q/A 31. The name of Christ was followed by introducing the name Christian in the parallel question. The order of prophet, priest and king in Q/A 31 was also applied in the answer to question 32. Especially the Catechism of Geneva could serve as an example (Hofius 1965).

The office names, however, were not used in answer 32 (as Ursinus had done in his Catechismus Maior (1562a)). Only the essential activity is mentioned: confessing Christ's name, presenting ourselves as sacrifice to him, to fight against sin and Satan, and reign with Christ forever. In some Dutch translations in the 20th century, these three characteristics of Christianity were explicated by adding: 'as prophet ... as priest ... as king ...' (Bakhuizen van den Brink 1976:168ff.; Gereformeerde Kerken in Nederland 2006). The original text of the Heidelberg Catechism has no such explication. In his commentary, Ursinus stated that 'Christ communicates his prophetic, priestly, and royal office (munus) to us' (Ursinus 1612a:144-147).

\section{Olevianus' A Firm Foundation}

The question who the primary authors of the Heidelberg Catechism were, does not concern us here. Closest in time, however, is the work of Ursinus and, less known, Caspar Olevianus' book A Firm Foundation (1567). Although it was published in 1567 , it was probably ready in 1563 , the year of publication of the Heidelberg Catechism. In later years Heinrich Alting told in his History of the Palatine Church in 1644 that having been commissioned to compose the HC, Ursinus and Olevianus:

each [...] wrote his own rough draft: Olevianus, a popular exposition of the covenant of grace; Ursinus, a twofold work a larger catechism for adults and a smaller one for the youth. From these two works the Heidelberg Catechism was composed. (Quoted by Bierma 1995:XV)

Bierma argues convincingly that Alting's description neatly fits the work that we know as Vester Grundt (now ably translated by him into English as A Firm Foundation). The book offers an exposition of Lord's Day 5-24, that is, roughly of the exposition of the Apostles' Creed of the Heidelberg Catechism. Yet, Olevianus adopted a more detailed division in questions and answers.

In A Firm Foundation, Olevianus speaks page after page on the meaning and comfort (nutz und trost) of the kingdom of Christ, of his priesthood and his being our teacher. He enumerates four benefits of Christ as our teacher. The fourth, to give one example, is that Christ does not keep this office and the power of the Spirit to himself, but communicates these to his body 'by revealing the will of his Father to each individual member':

He thus makes them prophets in two ways: first, by giving teachers to his church, through whose ministry he wishes to exercise his power and make family members and disciples for himself; second, by desiring that these disciples, that is believers, exercise the prophetic and teaching office even though they do 
not hold the public office of minister of the Word and sacrament. (transl. Bierma 1995:44; German text in Olevianus [1590] 1994:52)

How can the individual Christian be a prophet? Olevianus ([1590] 1994) elaborates:

There are three ways they can do this: by praising God with a sincere, public profession of the true faith [cf. Mk 8:36; Lk 9:26]; by instructing also their servants; and by building up their neighbours in the Lord, whenever there is the opportunity or possibility, without destroying the order that God has established in his Church. (p. 52ff.)

Finally, Olevianus raises this question: 'Now that you have said why the Son of God, revealed in the flesh, is called "Christ", that is "Anointed", explain why we are called Christians' (Q 61). The answer begins as follows:

Believers were first called Christians in Antioch; before that they were called brothers [...]. Hence we who believe in Jesus Christ are truly His brothers.

We are called Christians because we believe in Christ and are baptized in his name. This faith in Christ is the anointing that we have received from Christ and that remains ours forever, as John teaches [1 Jn 2:27). It is thereby that Christ, our beloved God, anoints us to be kings, priests, and teachers as members of Christ the Lord. We share in the spiritual gifts of Christ our head [...].

Therefore, this glorious appellation 'Christians' should remind us that we are no longer in the kingdom of the devil but in the kingdom of Christ, and that through faith and the testimony of holy baptism he has anointed us with his Holy Spirit [...] (transl. Bierma 1995:45; German text in Olevianus [1590] 1994:53-54).

Here the Lutheran connection of anointing and baptism is incorporated. It is Olevianus who exploits the teaching of Q/A 32 of HC.

It comes as a surprise to see that only three years after the publication of HC, the Catechismus Romanus also explicates the threefold office in explanation of the title Christ in the Apostolicum. This Catechism appeared in the wake of the Council of Trent in 1566. As Eusebius, Chrysostom and Fastidius had first recalled the offices in Israel, so the Catechismus Romanus reclaimed the patristic tradition, probably inspired by HC:

And truly, when Jesus Christ, our Saviour came into the world, He assumed the tasks and offices of these three roles, that is of Prophet, Priest, and King, and was therefore called Christ, having been anointed for the discharge of these functions, not by mortal hand or with earthly ointment, but by the power of his heavenly Father and with spiritual oil. (Catholic Church 1566:27-28)

Having retraced the background of Lord's Day 12 in the catechisms of the 16th century, we will look briefly at some examples in later catechetical and theological education in which this teaching was transmitted.

\section{From Leiden to Westminster}

In the wake of the Synod of Dordt the theological faculty of Leiden, purged of heterodoxy, resumed their cycle of disputations, which covered the whole range of systematictheological questions (Sinnema \& Van den Belt 2012). This cycle was published in 1625 as Synopsis of Sound Theology. ${ }^{7}$ Disputation 26 is dedicated to 'The Office of Christ' and consists in no less than 54 propositions.

At the beginning a first distinction is made between the person and office of Christ. On his office, a second distinction is proposed between the office as a whole and the distinct parts or aspects of that office. The general office in its unity is that of Christ being the Mediator, whilst, when the aspects are considered, his office is threefold: the prophetic, priestly and regal office (Polyander [1625] 1881:250 [Synopsis]). Proposition 37 is the beginning of the development of this second 'form of the office of the Mediator', which is seen clearly 'in the three parts and workings, which he carries out in his own right, that is in the prophetic, priestly and regal function' (Synopsis ibid:257). It should be noted that, whilst the Genevan Catechism taught three offices, the Leiden theologians do not speak of three offices (officia), but of three parts and functions (of the one office of the Mediator).

With regard to the prophetic work of Christ, the Synopsis speaks of Christ teaching the doctrine of Law and Gospel himself and through other ministers of the Word, that is, the prophets of old and his apostles (proposition 39). The next proposition even more clearly looks at the people of both the Old and New Testament as the object of Christ's prophetic work. Thus, the unity of Scripture and revelation history is located in the prophetic Christ. His priestly work is described as Christ appearing before God, fulfilling the Law, offering himself as expiatory sacrifice of our sins, and his intercession for our sake (proposition 42). This threefold work as priest is mirrored in the tasks of the Levites in keeping the Law, bringing sacrifices and praying on behalf of the people (proposition 43). Proposition 44 mentions Melchizedek in his double office of priest and king. Finally, Christ's task (munus) as king is defined in proposition 51, referring the readers to disputation 41 on Christ as the only Head of his church. The Synopsis thus made the catechetical material of the Genevan and Heidelberg Catechism, following the latter, into part and parcel of theological education at the beginning of the 17th century in the Netherlands. The theological formula of the threefold office of Christ was not so much developed as recycled for educational purposes.

In England, the Westminster Confession of Faith (WCF) (1976) does call the Lord Jesus 'the Mediator between God and man; the Prophet, Priest, and King; the Head and Saviour of his Church; the Heir of all things; and Judge of the world' (Ch. 8.1). These titles, however, play no systematic role in the development of soteriology. Only in the ecclesiology is he called 'King and head of his church' (Ch. 30.1). The Larger Catechism, however, devoted Q/A 42-45 to the threefold office of Christ. The point of departure is that our Mediator is called Jesus and, also, Christ:

Our Mediator was called Christ, because he was anointed with the Holy Spirit above measure; and so set apart and fully furnished with all authority and ability, to execute the offices of prophet, priest, and king of his church, in the estate both of his humiliation and exaltation. (WCF 1976:147-148)

7.The research group Classic Reformed Theology (Apeldoorn, Kampen \& Leuven) is preparing a critical edition and English translation of the Synopsis (to be published in three volumes, 2013-2015, at Brill Academic). 
The following three questions were asked after the execution of each office by Christ. It is remarkable that, in defining the execution of his kingship, the regal office is not only seen in his calling out of the world a people to himself, but also in 'giving them officers, laws, and censures, by which he visibly governs them' (A 45). At this point it is not clear whether ecclesiastical or civil rule is meant, but both are possible. The Shorter Catechism is only marginally shorter on the three offices of Christ (Q/A 23-26). Thus, the theological and catechetical summary of the meaning of the name Christ was transmitted in the reformed and presbyterian tradition of the 17 th century.

\section{Systematic theology for the 21th century}

After the 16th century, various theologians in the RomanCatholic tradition have taken up the concept of the triple office of Christ especially Johann Adam Möhler, George Phillips, John Henry Newman, Sebastian Tromp, and the encyclical Mystici Corporis of Pope Pius XII, Yves Congar, as well as the Vatican II Dogmatic Constitution on the Church Lumen gentuin (Beal 2011:97-102). In the protestant tradition, inspired by the Heidelberg Catechism, Beal refers to recent ecclesiological studies by Randall E. Otto, Gerry Breshears and the Trinitarian application by Christopher B. Kaiser and Robert Sherman (Beal ibid:106). To these we would like to add the Christological works of Immink and Welker.

A first Christology, focusing on the work of Jesus Christ and built on the structure of the threefold office, is those of Gerrit Immink's Jezus Christus: Profeet, priester, koning (Immink 1990). One of the aspects to which he drew attention is the anthropological component, meaning the threefold salvation. As a prophet, Christ brings us knowledge of the Lord. As high priest, Christ brings reconciliation with God. As king, Christ brings us under God's rule. These relations correspond with the human mind, his will and his heart. Immink calls the threefold office a fruitful paradigm, which he demonstrated by listing five positive aspects (one of these is the anthropological one, as mentioned above).

At the conference of the International Reformed Theological Institute in Potchefstroom in July 2011, Michael Welker spoke on the development of Christology since the Reformation. In his recent book on Christologie, he developed what he calls one of Calvin's Christological key-insights, namely that of the threefold office of Christ. This insight connects the life of Christ before Easter ('das vorösterliche Leben Jesu') and his eschatological life since his resurrection ('sein nachösterliche Leben'). Welker quotes Institutes II.15.1 as his baseline and develops his Christological concept from there.

On the one hand, Welker remarks briefly that the doctrine of the munus triplex Christ has been developed in various theological traditions and can therefore be regarded as a unique oecumenical phenomenon (according to Edmund Schlink; cf. Hofheinz in press:379-382). Johann Gerhard (Beal
2011) introduced this concept of Christ's threefold office into Lutheran theology. It was also developed in RomanCatholic and Eastern-Orthodox theology. On the other hand, he used the concept of the threefold office of Christ himself to structure his work on Christology. Parts 4 and 5 are built upon this concept. To mention only the headlines:

- Christ's royal presence amongst his own and the liberating power of love, which leads to a serving existence of the Church and a Christian humanism (§ 4.4).

- Christ's priestly presence amongst his own and the liberating power of faith, which shapes Church service and baptism as transference of Lordship (\$ 5.3).

- Christ's prophetic presence amongst his own and the liberating power of hope, expressing itself in Christological and biblically orientated preaching a truth and justice seeking communities ( $\$ 5.5)$.

Further analysis of Welker's Christological concept lies beyond the scope of this article. Our brief introduction may suffice to illustrate how the concept of the threefold office of Christ developed into its clearest and most widespread expression in HC Lord's Day 12. When developing this Christological concept and applying it to Christian life today, one last thought, underlined by Welker, is important. He stated that the three offices must not be seen as separate ones. 'The three offices penetrate each other, they are interconnected perichoretically' (Welker 2012:201). The term perichorese is used for the unity of the three Persons in the trinity. It is better to speak of the one 'threefold office' than of 'the three offices' of Christ. Earlier Verboom (2008:235) said in more practical terms: 'This mutual coherence means in particular, that the prophet's confessing is directly connected with the priest's suffering and the king's fighting.' Thus, prophecy, passion and power are highly qualified characteristics for followers of Jesus Christ. We cannot claim one without living the others.

Prophecy is not our claim on truth and short-sighted private messages, but outspoken loyalty to the Scriptures that testify Christ as our Master. The passion of a Christian is not unrestrained emotion, but willingness to love and to suffer. The power of Christians is not economic or political control, but the struggle to overcome sin and evil.

\section{Conclusion}

There is no single text from the Bible where the three offices are singled out from the structures of the Old Testament and applied together to Christ. The figure of Melchizedek, the priest-king of Psalm 110, is a type of Christ, as explained in the Letter to the Hebrews. This Letter attributes the full realisation of the office of high priest to Christ. The attribution of the three offices to Christ was born from a systematic reflection on Scriptural passages. Having retraced the origin of this concept in 16th century reformed theology, the value of employing the threefold office of Christ in catechetical teaching and systematic theology can be expressed in a number of points:

- It ties the Old and New Testament history together with a centre point in the Gospel narratives on Jesus Christ. 
The concept of the threefold office forbids an evangelical omission of God's rule of Israel.

- These roots of the three offices, also in the time of the diaspora, can be a point of discussion between rabbinical scholarship and Jewish expectation of the Messiah and Christian theology.

- The Christological part of Lord's Day 12 (Q/A 31) is an ever-present corrective for the ecclesiological part $(\mathrm{Q} / \mathrm{A}$ 32). The fact that we do not speak of the three offices, but of the one and threefold office of Christ, must be maintained in ecclesiology.

- The catechetical potency of this concept must be reappropriated in explaining God's rule of Israel by prophets (normative rule), priests (spiritual rule) and kings (civil rule), and in application to the day-to-day life of a Christian in a multi-cultural and religious society.

- The potential of the concept of the threefold office of Christ can be evaluated in the light of systematic theological reflection (Immink 1990; Welker 2012).

\section{Acknowledgements Competing interests}

The author declares that he has no financial or personal relationship(s) that may have inappropriately influenced him in writing this article.

\section{References}

Bakhuizen van den Brink, J.N. (ed.), 1976, De Nederlandse belijdenisgeschriften, 2nd edn., Uitgeverij Ton Bolland, Amsterdam.

Barth, P. \& Niesel, G. (eds.), 1970, loannis Calvini opera selecta, 2nd edn., Chr. Kaiser, München. [= OS II]

Beal, R.M., 2011, 'Priest, Prophet, King: Jesus Christ, the Church and the Christian Person', in G. Mannion \& E. van der Borght (eds.), Calvin's Ecclesiology: Ecumenical Perspectives, pp. 90-106, T\&T Clark, London.

Bierma, L., 1995, Caspar Olevianus. A Firm Foundation: An Aid to Interpreting the Heidelberg Catechism, transl. L. Bierma (ed.), Baker Books, Grand Rapids, MI.

Brenz, J., 1553, Catechismus pia et utili explicatione illustrates, Wittenberg.

Bucer, M., 1528, Martini Buceri opera latina, Enarratio in evangelion lohanni (1528, 1530, 1536), vol. 2, E.J. Brill, Leiden/New York/Köln.

Bucer, M., 1987, Martin Bucers Deutsche Schriften, Martin Bucers Katechismen aus den Jahren 1534, 1537, 1543, vol. 3/6, Gütersloher Verlagshaus Gerd Mohn, Gütersloh.

Calvin, J., 1539, 'Institutio religionis christianae', in Opera quae supersunt Omnia, vol. 1 , Strasbourg.

Calvin, J., 1559, 'Institutio religionis christianae', in Opera quae supersunt Omnia, vol. 2, Strasbourg

Calvin, J., [1538] 2002, 'Ioannis Calvini scripta ecclesiastica', in A. Zillenbiller (ed.), Instruction et confession de foy dont on use en l'Eglise de Genève / Catechismus seu Christianae religionis institutio ecclesiae Genevensis, vol. 2, Librairie Droz, Genève.

Calvin, J., 2008, Institution de la Religion chrétienne (1539/1541), 2 vols., O. Millet (ed.), Librairie Droz, Genève.

Calvyn, J., 1542, Calvyn se Kategismus, Potchefstroomse Teologiese Publikasies, Potchefstroom.
Catholic Church, 1566, Catechismus Romanus, Plantijn, Antwerpen.

Chrysostom, J., 1862, 'Homilia III in epistolam II ad Corinthos', in J-P. Migne (ed.), Patrologia series graeca, vol. 61, pp. 405-418, Paris.

d'Assonville, V.E., 2013, 'Prophet, Doctor Jesus: The Son of God as "our high priest and teacher" in the Heidelberg Catechism', in J.D Payne \& S. Heck (eds.), The Heidelberg Catechism's Enduring Heritage, pp. 181-194, Reformed Heritage Books, Grand Rapids.

De Boer, E.A., 2009, Binnen- of buitenkant? Wat christenmensen kenmerkt. Het menselijk gezicht van artikel 29 van de Nederlandse Geloofsbelijdenis in de 'notae christianorum' als ecclesiologisch accent tussen de 1e en 21e eeuw, Vrije Universiteit, Amsterdam, viewed 01 December 2012, from http://dare.ubvu. vu.nl/bitstream/handle/1871/15728/De\%20Boer_Inaugurele\%20oratie_OCR.pdf ;jsessionid=E6EABFD61B2B6D91E52CF1EB0B2F2794? sequence $=2$.

Eusebius, 1973, 'Historia ecclesiastica', in J.E.L. Oulton (ed.), Loeb Christian Classics, Cambridge University Press, London. [= Hist. eccl.]

Fastidius, 1865, 'De vita Christiana', in J-P. Migne (ed.), Patrologia series latina vol. 50 , pp. 383-402, Paris.

Faulenbach, H. \& Busch, E. (eds.), 2006, Reformierte Bekenntnisschriften Bd. 1/2: 1535-1549, Neukirchner Verlag, Neukirchen. [= RB 1/2]

Gereformeerde Kerken in Nederland, 2006, Gereformeerd Kerkboek van de Gereformeerde Kerken (vrijgemaakt) in Nederland, Heerenveen, Netherlands.

Gooszen, M.A., 1890, De Heidelbersche Catechismus, textus receptus met toelichtende teksten. Bijdrage tot de kennis van zijne wordingsgeschiedenis en van het Gereformeerd protestantisme, Brill, Leiden, viewed 01 December 2012, from www.kerkrecht.nl

Gooszen, M.A., 1893, De Heidelbersche Catechismus en het boekje van de breking des broods, in het jaar 1563-64 bestreden en verdedigd. Oorkonden en dogmenhistorisch onderzoek, Brill, Leiden.

Hofheinz, M., (in press), 'De oecumenische betekenis van de Heidelbergse Catechismus', in A. Huijgen, J.V. Fesko \& A. Siller (eds.), Handboek Heidelbergse Catechismus', in A. Huijgen, J.V. Fesko \&
Catechismus, pp. 371-382, Kok, Utrecht.

Hofius, O., 1965, 'Zu Frage 32 des Heidelberger Katechismus,' Reformierte Kirchenzeitung 106(13), 143-145.

Huijgens, A., Fesko, J.V. \& Siller, A. (eds.), 2013, Handboek Heidelbergse Catechismus, Kok, Utrecht.

Immink, F.G., 1990, Jezus Christus: Profeet, priester, koning, Kok, Kampen. PMid:2136513

Lang, A., 1907, Der Heidelberger Katechismus und vier verwandte Katechismen (Leo Jud's und Micron's kleine Katechismen, sowie die zwei Vorarbeiten Ursins) mit einer historisch-theologischen Einleitung, Deichert, Leipzig.

Mühling, A. \& Opitz, P. (eds.), 2009, Reformierte Bekenntnisschriften Bd. 2/2: 15621569, Neukirchner Verlag, Neukirchen. [= RB 2/2]

Olevianus, C., 1567, Vester grund, viewed 01 December 2012, from http://www.prdl.org/ Olevianus, C., [1590] 1994, Der Gnadenbund Gottes, G. Franz, J.F.G. Goeters \& W. Holtmann (eds.), Köln/Bonn.

Polyander, J., Rivetus, A., Walaeus, A., Thysius, A. \& Bavinck, H. (eds.), [1625] 1881 Synopsis Purioris Theologiae, Leiden. [= Synopsis]

Sinnema, D. \& Van den Belt, H., 2012, 'The Synopsis Purioris Theologiae (1625) as a Disputation Cycle', Church History and Religious Culture 92(4), 505-537. http:// dx.doi.org/10.1163/18712428-09220072

Ursinus, Z., 1562a, Catechismus Maior, viewed 01 December 2012, from http://www. prdl.org/

Ursinus, Z., 1562b, Catechismus Minor, viewed 01 December 2012, from http://www. prdl.org/

Ursinus, Z., 1612a, 'Catechesis, summa theologiae', in Q. Reuter (ed.), Opera Theologica 1, pp. 144-147, Heidelberg.

Ursinus, Z., 1612b, 'Explicationes Catecheseos Palatinae, sive corpus Theologiae', in Q. Reuter (ed.), Opera Theologica 1, pp. 46-413, Heidelberg.

Verboom, W., 1996, De theologie van de Heidelbergse Catechismus. Twaalf thema's: de context en de latere uitwerking, Boekencentrum, Zoetermeer.

Verboom, W., 2008, 'Why are you called a Christian? Question 32 of the Heidelberg Catechism', in E. van der Borght (ed.), Christian Identity, pp. 225-237, Brill, Leiden/ Boston. http://dx.doi.org/10.1163/ej.9789004158061.i-514.100

Welker, M., 2012, Gottes Offenbarung. Christologie, 2nd edn., Neukirchener Theologie, Neukirchen.

Westminster Confession of Faith, 1976, The Confession of Faith, the Larger and Shorter Catechisms with the Scripture Proofs at Large, together the sum of saving knowledge, Free Presbyterian Church of Scotland, Scotland. [= WCF] 